\title{
Determinants of the Entrepreneurial Influence on Academic Entrepreneurship-Lessons Learned from Higher Education Students in Portugal
}

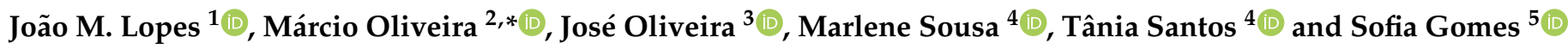 \\ 1 Miguel Torga Institute of Higher Education \& NECE-UBI-Research Unit in Business Sciences, \\ University of Beira Interior, Estrada do Sineiro, s/n, 6200-209 Covilhã, Portugal; \\ joao.lopes.1987@hotmail.com \\ 2 NECE-Research Unit in Business Sciences, ISLA Santarém-Instituto Superior de Gestão e Administração \\ de Santarém, Largo Cândido dos Reis 2000-241 Santarém, and Polytechnic Institute of Leiria, Rua General \\ Norton de Matos, Apartado 4133, 2411-901 Leiria, Portugal \\ 3 ISPGAYA, Av. dos Descobrimentos 333, 4400-103 Vila Nova de Gaia, Portugal; jcastroliveira@gmail.com \\ 4 CICS.NOVA-Interdisciplinary Center of Social Sciences, Polytechnic Institute of Leiria, \\ Rua General Norton de Matos, Apartado 4133, 2411-901 Leiria, Portugal; marlene.sousa@ipleiria.pt (M.S.); \\ tania.santos@ipleiria.pt (T.S.) \\ 5 REMIT-Research on Economics, Management and Information Technologies, University Portucalense, \\ R. Dr. António Bernardino de Almeida 541, 4200-072 Porto, Portugal; sofiag@upt.pt \\ * Correspondence: marcio.oliveira@ipleiria.pt
}

\section{check for} updates

Citation: Lopes, J.M.; Oliveira, M.; Oliveira, J.; Sousa, M.; Santos, T.; Gomes, S. Determinants of the Entrepreneurial Influence on Academic Entrepreneurship_Lessons Learned from Higher Education Students in Portugal. Educ. Sci. 2021, 11,771. https://doi.org/10.3390/ educsci11120771

Academic Editors: Jacinto Jardim and Maria José Sousa

Received: 5 October 2021

Accepted: 16 November 2021

Published: 29 November 2021

Publisher's Note: MDPI stays neutral with regard to jurisdictional claims in published maps and institutional affiliations.

Copyright: (c) 2021 by the authors. Licensee MDPI, Basel, Switzerland. This article is an open access article distributed under the terms and conditions of the Creative Commons Attribution (CC BY) license (https:/ / creativecommons.org/licenses/by/ $4.0 /)$.

\begin{abstract}
Academic entrepreneurship is becoming increasingly important to the field of research as well as to policy makers due to its ability to contribute to the economic, technological, and social development of regions and countries. This research aims to evaluate the determinants that influence the interest of Portuguese higher education students (HEI's) to become entrepreneurs. The methodology used is quantitative and uses structural model equations. The results obtained demonstrate that the student's perception of business skills, business growth skills, strategy, and successful business are key factors that students take into account in their entrepreneurial orientation. The research contributes to this theory by adding new knowledge to the literature on the perception of the HEI's students to become entrepreneurs, specifically the students of Portuguese universities. In practical terms, the contributions offered within this research are based on suggestions for the third mission of universities, explicitly knowledge transfer to the community, business groups, and policy makers, as well as the creation of the essentials within university boundaries to promote entrepreneurship amongst its students. The research is original and innovative, as no research on this field with all the aggregated elements under study has been previously performed in Portugal. Furthermore, the obtained results can translate into ideas that potentially create jobs.
\end{abstract}

Keywords: academic entrepreneurship; entrepreneurial intention; entrepreneurial attitude; business skills

\section{Introduction}

In the last decades, entrepreneurship has been a phenomenon that has attracted increasing interest from some of the different regional actors in a globalized and knowledgebased global economy [1,2]. Entrepreneurship is a driver of sustainable regional economic development and a catalyst of innovation, which in turn increases job creation $[3,4]$.

In this context, policy makers are generally aware that entrepreneurship should be a priority for the development of any region. Thus, government officials constantly try to accelerate the creation of entrepreneurial ecosystems, providing financial support through policy development, and education programs for entrepreneurship and innovation [5-7]. As such, they intend to create an environment that favors and assists students in higher 
education to start their own companies [3,8]. However, the number of companies created by graduate students has not increased significantly [9], on the contrary, it is falling below the level idealized by regional governments and universities [10].

Over time, universities have evolved to adapt to the market needs and their students' expectations. Nowadays, the mission of universities is no longer focused on teaching and research (the universities' first and second mission). A third mission of the universities emerged, the entrepreneurial university, which ensures that they are involved in the transfer of knowledge to the local community, through entrepreneurial activities [11-13]. The third mission of the universities expects to give contributions to the social and economic development of the regions where they operate [14].

Within this context, in 2014, European Union policy makers changed their regional development policies, which are called research and innovation strategies for smart specialization (RIS3). RIS3 is based on the concept of smart specialization in areas and regions that have traditions [15]. In this manner, it is expected that the regions will be able to increase their innovative performance, and also seek to have a regional economy, progressively based on technology [16,17].

Studies on academic entrepreneurship have been performed over time. Some studies were focused on the personality traits of individuals and how they influenced the promotion of entrepreneurial intentions [18-20]. Other studies highlighted the relevance of the interaction between individual and contextual factors in the investigation of entrepreneurship and innovation [21,22]. Nonetheless, there are already studies that focus on individual characteristics, such as entrepreneurial mindset, traits, and personality [23], and gender [24]. Some studies consider family history as parents' employment status and occupational status [25], as well as previous exposure to companies that are family owned [26]. Socio-environmental factors, such as regional policy, have also been considered in the study of academic entrepreneurship [27].

Despite the previously mentioned facts, societies are evolving, and the shifting conjunctures bring new challenges. With this evolution, the competition between companies is becoming fierce, innovation and entrepreneurship is being constantly encouraged, consequently leading the world to become more and more global. Thus, the climate of uncertainty has grown and the accelerated development of technology brought changes in social behavior. Education for entrepreneurship has a fundamental role to prepare citizens to be talented and prepared to face the impact resulted from globalization and social transformation $[1,28,29]$. Education should always be adjusted to these new needs. Being so, it is still necessary and pertinent to further investigate the various factors that affect academic entrepreneurship [3,30]. According to Anjum, et al. [31] and Dentoni, Pinkse and Lubberink [3], it is important to study the entrepreneurial intention in students from different countries and different educational backgrounds.

That said, the present research aims to evaluate the determinants that influence the interest of Portuguese higher education students to be entrepreneurs. This research brings new contributions as it contemplates variables that have been little explored in academic entrepreneurship such as business growth, skills, strategy, and success. From a launched questionnaire, 1114 responses were collected, and the results indicate that business growth has a positive impact on students' willingness to become entrepreneurs. It also indicates that greater business skills have a positive impact on students' willingness to become entrepreneurs. It was also confirmed that the use of business strategy for business expansion has a positive impact on the entrepreneurial attitude. Moreover, we have also corroborated that the appreciation of business success factors has a positive impact on students' willingness to become entrepreneurs.

This research begins with an introduction where the problem under study and the respective objective is presented. In part two, the literature on academic entrepreneurship is extensively reviewed and hypotheses formulated. In part three the full methodological process and data collection methods are detailed. In part 4 the results are presented, discussed, and compared with the literature. Finally, the conclusions and main findings are 
presented as well as theoretical and practical contributions, followed by limitations and clues for future investigations.

\section{Theoretical Framework, Structural Model, and Research Hypotheses}

\subsection{Theoretical Framework}

\subsubsection{Entrepreneurial Intention}

The term "intention" is defined by Ajzen [32] as "indications of a person's readiness to perform a behavior" (p. 1122). In the business context, Bird [33,34], and Fini, et al. [35] understand the concept of entrepreneurial intention as a state of mind that guides attention, experience, actions, goal setting, commitment, and other aspects of an individual's life to represent entrepreneurial behavior. Entrepreneurial intention is a broad concept, which translates a continuous behavior and reveals aspects as diverse as the preference for self-employment instead of employment by others, the entrepreneurial career itself, and emerging entrepreneurship [36].

According to the contributions by Linan, et al. [37], Ajzen [38], North [39], Anderson and Jack [40], and Liñán and Santos [41], the influence on the entrepreneurial attitude can be differentiated by factors such as: (a) motivational factors, (b) environmental factors, and (c) control variables.

\section{(a) Motivational factors}

The motivational factors come from the "planned behavior approach", according to which an individual is motivated to accept due to three factors: "attitude towards behavior", "perceived behavior control", and "subjective norms". The attitude towards behavior is related to the assessment (positive or negative) that the individual has about being an entrepreneur, a factor that determines the attractiveness of entrepreneurship and, therefore, his entrepreneurial intention [38,42-44]. The element "perceived behavior control" reveals the individual's perception of the ease or difficulty of being an entrepreneur and his ability to control this behavior [42], a factor directly related to entrepreneurial intention [43,45-47]. The subjective norms measure the social pressure perceived by the individual's reference persons, such as family, friends, or peers [32,42].

\section{(b) Environmental factors}

Social Learning Theory considers that environmental factors affect the cognitive process and, therefore, may influence the entrepreneurial intention [39]. Several studies reveal the importance of culture in behaviors towards entrepreneurship [48-50], and define that factors such as values, norms, and ideas are common to a certain group of people [51]. These shared values and ideas established from the interaction between people influence the development of entrepreneurship [40,52,53].

\section{(c) Control variables}

Control variables are demographic variables that help to define the entrepreneur profile, including age, gender, educational qualifications, and labor market experience. We found several studies that deal with the influence of these variables on the propensity to create new companies [34,48,54]. Studies by Ajzen [42], Armitage and Conner [55], Hoang and Antoncic [52], Huang, et al. [56], and Kraft and Bausch [57] also lead us to conclude that elements such as perceived self-efficacy and affective attitude are considered more important to understand the entrepreneurial intention than perceived controllability.

The study by Linan, Urbano and Guerrero [37] found evidence about the influence of the macroeconomic environment in the formation of entrepreneurial intention. Also, the investigation of Covin and Lumpkin [58] detected the influence of culture, environment, and organizational behavior in entrepreneurial orientation. Furthermore, Welter and Smallbone [59] and Musteen, et al. [60] refer to the entrepreneurial intention as influenced by the individuals' perceptions concerning social and cultural norms and institutions in which they are inserted. 
One way to understand entrepreneurial intent is to examine cognitive structures, as well as entrepreneurial attitudes, intentions, and actions that are inherent to it [46]. Evidence indicates that the cognitive level is influenced by the individual perceptions of entrepreneurship, along with personal, sociological, and environmental elements [37,45,48,61-63]. Based on a model developed from the theory of planned behavior $[38,45,64]$, institutional economic theory [39], and social capital theory [40,41], and using structural equation techniques, the authors compare the entrepreneurial intentions of university students from two Spanish regions, Catalonia and Andalucia, and conclude that the valuation of entrepreneurship in each region influences regional differences in terms of entrepreneurial intentions. The authors identified the environmental elements that can explain regional differences in terms of entrepreneurial intentions, including "social climate" and "individual perception differences". Therefore, it was concluded that the social valuation of the entrepreneur was superior in the most developed region, positively affecting the subjective perception of standards and behavioral control. Conversely, in the most economically disadvantaged region, the influence of reference persons in the social perception of the entrepreneur is more valued, affecting the attitude towards the behavior and subjective interpretation of the norms. These results justify the need for public policies to promote more positive entrepreneurial values in relatively backward regions.

Following the designation assigned by North [39], Linan, Urbano and Guerrero [37] differentiate the informal factors (attitudes, beliefs, values) from the formal factors (norms, regulations, financing, advising, instruments to support entrepreneurship) in the formation of entrepreneurial intention.

\subsubsection{Academic Entrepreneurship}

Academic entrepreneurship is the process by which individuals integrate into universities or research centers the knowledge created in the scope of research to generate business ventures or spin-offs [65].

Academic entrepreneurship falls within the scope of the third mission of the universities, a multidisciplinary approach framed in the institution's economic and social mission and its contribution to the community and the territory, contributing to the social, economic, and cultural development of the regions where they operate through the transfer of knowledge and technology on a large scale $[66,67]$. The role of the university in the transfer of technology has evolved in recent years, translating into the transition from a "triple helix" model, based on the interrelationship between academy/industry/regional government, passing on the increasingly complex network of regional partners. This complexity resulted in a "quadruple helix" model when integrating societal based innovation users [68-71].

Numerous studies show the importance of academic entrepreneurship in the development of entrepreneurial attitudes, as well as in the entrepreneurial intention and the creation of companies [17,65,72,73]. Neves and Brito [17] propose to identify the drivers of academic entrepreneurial intentions and concluded that there are multiple push factors, dependent on the context and the hierarchy. According to Nabi, et al. [74], the purpose of entrepreneurship education is to improve student's business skills to create a desire for them to be entrepreneurs.

Based on the theory of planned behavior, one of the most cited models to understand and predict human social behavior, Vamvaka, Stoforos, Palaskas and Botsaris [72] present a study that intends to identify the gender-related differences and their interrelationships with an entrepreneurial attitude, perceived behavioral control, and entrepreneurial intention amongst Greek undergraduate students. They could detect the importance of emotions in the entrepreneurial process, as they find that the entrepreneurial intention is strongly related to the students' affective attitude and their perceived self-efficacy. Vamvaka, Stoforos, Palaskas and Botsaris [72] also found that gender difference aspects such as commitment to entrepreneurship and emerging entrepreneurship are weaker in female than in male undergraduate students. 
Other studies reveal factors related to the business as drivers of the entrepreneurial attitude [75] and consider that the evidence on business strategies that show good performance provokes an increase in interest in entrepreneurial operations. Kristiansen and Indarti [76], applied a study to Indonesian and Norwegian juveniles, to evaluate the influence of demographic and individual background factors, personality traits, and attitudes, as well as contextual elements, such as access to capital and access to information, in the entrepreneurial intention. They conclude that individual perceptions of self-efficacy and instrumental readiness are affecting and affecting young people's entrepreneurial intent. On the contrary, age, gender, and educational background have no significant impact. The lower level of entrepreneurial intent is explained by the perceived social status and low remuneration expected from entrepreneurs, with these elements functioning as demotivating factors for entrepreneurship.

Creativity is an important characteristic of the entrepreneur, and there is a relationship between creativity and business success, as the entrepreneur will take advantage of ideas and opportunities, acting towards the optimization of resources, to create an efficient and innovative process $[77,78]$.

The importance attached to business growth is also relevant to the desire of becoming an entrepreneur. According to Birley, et al. [79] and Donckels and Lambrecht [80], entrepreneurs who contact colleagues involved in business, and have knowledge about businesses with a high growth propensity, result in making their investment decisions based on this knowledge (international business ends up attributing relevance to their partners/colleagues in decision-making).

\subsection{Structural Model and Research Hypotheses}

Since the main objective of this research is to evaluate the determinants that influence the desire of Portuguese higher education students to be entrepreneurs, grounded on the literature review, a methodological framework was constructed based on the structural model of Linan, Urbano and Guerrero [37], in which the entrepreneurial intention depends on environmental factors (closer valuation and social valuation) and motivational factors (perceived behavioral control and attitude towards the behavior). Focusing on the motivational factors, the will to be an entrepreneur depends on Entrepreneurial Attitude which, in turn, depends on Perceived Behavior and Entrepreneurial Attitude [37]. Moreover, Entrepreneurial attitude will still be influenced by the business strategy that each entrepreneur wants to develop for his business [81,82]. On the other hand, the desire to be an entrepreneur will depend on business skills [83,84], a wish to grow the business $[85,86]$, and the importance that entrepreneurs attach to business success $[34,87]$. As such, they were added to the motivational factors of the entrepreneurial intention of Linan, Urbano and Guerrero [37], with the following determinants: Business Strategy, Business Growth, Business Success, and Business Skills, resulting in the structural model presented in Figure 1.

This structural model focuses on eight latent variables, with three endogenous latent variables (Entrepreneurial Attitude, Entrepreneurial Intention and Being an Entrepreneur) and five exogenous latent variables (Business Strategy, Business Growth, Business Success, Business Skills, and Perceived Behavior). Amongst the latent variables, direct and indirect relationships were established. In terms of direct relationships, we have Business Growth, Business Success, Business Skills influencing Being an Entrepreneur, and indirect relationships are Business Strategy $>$ Entrepreneurial attitude $>$ Being at Entrepreneur; Perceived behavior $>$ Entrepreneurial attitude $>$ Being an Entrepreneur.

Based on the main objective of this research, aiming to evaluate the determinants that influence the will of the Portuguese to be entrepreneurs and on the structural relationships that appear in the structural model, the following hypotheses were formulated:

Hypothesis 1 (H1). The importance attached to Business Growth has a positive impact on the will to be an entrepreneur.

Hypothesis 2 (H2). Greater Business Skills have a positive impact on the will to be an entrepreneur. 
Hypothesis 3 (H3). The use of Business Strategy for business expansion has a positive impact on Entrepreneurial Attitude.

Hypothesis 4 (H4). The appreciation of Business Success factors has a positive impact on the will to be an entrepreneur.

Hypothesis 5 (H5). Entrepreneurial Attitude has a positive impact on Entrepreneurial Intention.

Hypothesis 6 (H6). Entrepreneurial Intention has a positive impact on the will to be an entrepreneur.

Hypothesis 7 (H7). Perceived Behavior has a positive impact on Entrepreneurial Intention.

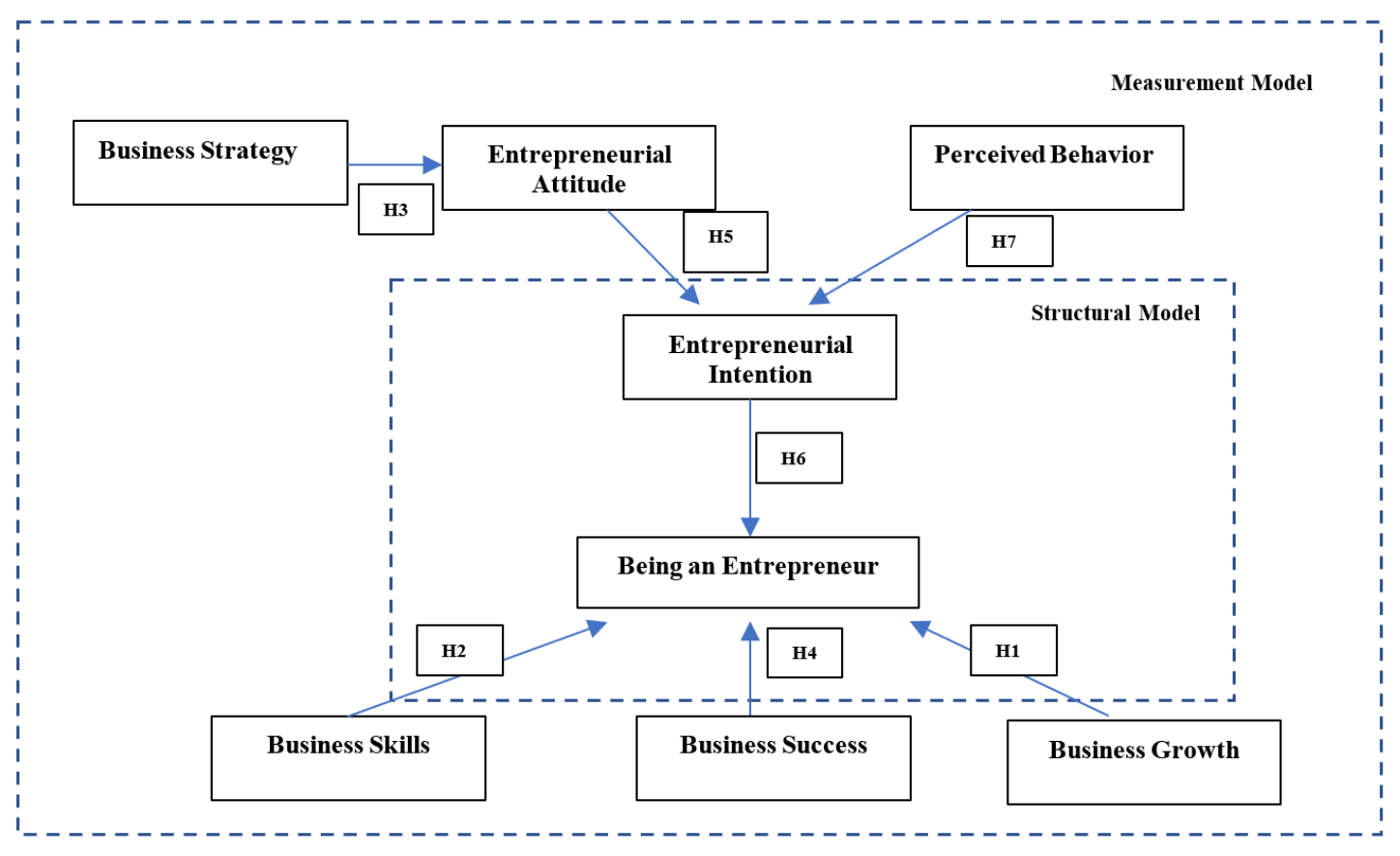

Figure 1. Structural model.

\section{Methodology and Data Collection}

To accomplish the main objective of this research, a quantitative methodology was chosen. This type of methodology has been widely used to develop studies on entrepreneurship [88,89]. Its main advantages are to allow the validation of theories and relationships between variables, generalize results, and replicate methods and techniques in new samples [90-92]. Furthermore, a questionnaire was used as a tool for data collection.

The questionnaire applied in this research was previously used in studies of Linan, Urbano and Guerrero [37] and Lopes, Teixeira, Ferreira, Silveira, Farinha and Lussuamo [30]. We collected a sample of 1114 observations through an online questionnaire that was applied to higher education students in Portugal between April 2017 and December 2020. Students attend courses in business science (management and related) in which the subject of entrepreneurship is taught, and as such, their course includes in its syllabus all important and emerging topics of entrepreneurship. A convenience sampling method was used. Initially, we search for HEIs located in Portugal. For this purpose, an online database containing Portuguese HEIs was used (https:/ / www.universia.net/pt/universidades.html, accessed on 20 August 2021). From the outcome of the online database, 60 Portuguese HEIs were contacted. The objective of this contact was to request the distribution of a questionnaire to their students via email. From the HEIs contacted, 14 responded positively, referring that they would distribute the questionnaire amongst their students, 30 responded negatively denoting that they do not send questionnaires to their students, and 16 did not 
reply at all. Moreover, the questionnaire was also disseminated in social networks, namely Facebook and Twitter.

The questionnaire consisted of nine groups of questions: (1) Entrepreneurial Intention with four questions; (2) Perceived Behavior with four questions; (3) Entrepreneurial Attitude with three questions; (4) Business Strategy with eight questions; (5) Business Growth with a question; (6) Business Success with seven questions; (7) Business Skills with six questions; (8) Being an Entrepreneur with one question, and (9) Sociodemographic characteristics with four questions related to age, sex, residence, and employment experience.

All the groups of questions mentioned above use a 7-point Likert scale, except for questions related to sociodemographic characteristics. In the groups of questions related to Entrepreneurial Intention (G1), Perceived Behavior, and Entrepreneurial Attitude a scale where 1-strongly disagree to 7-strongly agree is used; the Business Strategy questions group uses a scale where 1-not likely to 7-extremely probable; the Business Growth and Business Success question groups use a scale where 1-not important and 7-extremely important; the Business Skills question group uses a scale where 1 -no aptitude and 7total aptitude and the question about Being an Entrepreneur uses a scale where 1-not at all attractive and 7-extremely attractive.

Regarding sociodemographic characteristics (Table 1), respondents are mostly women $(65.6 \%)$ and have an average age of 26.53 years. A total of $76.8 \%$ respondents are under 30 years old, $31.6 \%$ are under 20 years old, and $45.2 \%$ are over 21 years old and less than 30 years old. In terms of residence, $83.8 \%$ live in mainland Portugal, $9 \%$ in the Azores, and $7.2 \%$ in Madeira. Most respondents are studying or have an undergraduate degree $(67.6 \%)$ and $68.9 \%$ have professional experience.

Table 1. Statistics of sociodemographic characteristics.

\begin{tabular}{cccc}
\hline & Frequency & Valid Percent & Cumulative Percent \\
\hline Gender & & & \\
\hline Female & 731 & 6.6 & 65.6 \\
Male & 383 & 34.4 & 100 \\
\hline Age & & & 31.6 \\
\hline Less than 20 years & 350 & 31.6 & 76.8 \\
Between 21 and 30 years & 503 & 45.2 & 88.4 \\
Between 31 and 40 years & 129 & 11.6 & 100 \\
More than 40 years & 132 & 11.6 & \\
\hline Residence & & & 93.8 \\
\hline Portugal Mainland & 934 & 83.8 & 100 \\
Azores & 100 & 9 & 31.1 \\
Madeira & 80 & 7.2 & 100 \\
\hline Job experience & & & \\
\hline No & 347 & 31.1 & 67.6 \\
Yes & 767 & 68.9 & 100 \\
\hline Education level & & &
\end{tabular}

Regarding the question groups of Entrepreneurial Intention, Perceived Behavior, Entrepreneurial Attitude, Business Strategy, Business Growth, Business Success, Business Skills, and Being an Entrepreneur, the mean and standard deviation of the answers are found described in Table 2. 
Table 2. Mean and standard deviation of the responses to the questionnaire.

\begin{tabular}{|c|c|c|}
\hline & Mean & Std. Deviation \\
\hline \multicolumn{3}{|l|}{ Entrepreneurial Intention } \\
\hline A04.-I am ready to do anything to be an entrepreneur & 4.24 & 1.69 \\
\hline A06.-I will make every effort to start and run my own business & 4.89 & 1.781 \\
\hline A13.-I am determined to create an enterprise in the future & 4.47 & 1.682 \\
\hline A17.-My professional goal is to be an entrepreneur & 3.75 & 1.84 \\
\hline \multicolumn{3}{|l|}{ Perceived Behavior } \\
\hline A01.-Starting a company and keeping it viable would be easy for me & 3.78 & 1.456 \\
\hline A07.-I am able to control the process of creating a new business & 4.6 & 1.518 \\
\hline A14.-If I try to start a business, I will have a high chance of being successful & 4.64 & 1.365 \\
\hline A20.-I know all about the practical details needed to start a business & 2.93 & 1.652 \\
\hline \multicolumn{3}{|l|}{ Entrepreneurial Attitude } \\
\hline A10.--If I had the opportunity and the resources, I would love to start a business & 5.74 & 1.581 \\
\hline A15.-Being an entrepreneur would give me great satisfaction & 5.07 & 1.712 \\
\hline A18.-Being an entrepreneur implies more advantages than disadvantages for me & 4.29 & 1.577 \\
\hline \multicolumn{3}{|l|}{ Business Skills } \\
\hline D1.-Opportunity recognition & 4.89 & 1.278 \\
\hline D2.-Creativity & 5.02 & 1.388 \\
\hline D3.-Problem solving skills & 5.39 & 1.16 \\
\hline D4.-Leadership and communication skills & 5.28 & 1.294 \\
\hline D5.-Development of new products and services & 4.58 & 1.344 \\
\hline D6.-Formation of networks and professional contacts & 4.61 & 1.439 \\
\hline \multicolumn{3}{|l|}{ Business Success } \\
\hline 7.a. Effective competition on world markets & 5.29 & 1.314 \\
\hline 7.b. Achieve a high level of income & 5.6 & 1.175 \\
\hline 7.c. Do the kind of work that I really appreciate & 6.16 & 1.147 \\
\hline 7.d. Achieve social recognition & 5.38 & 1.439 \\
\hline 7.e. Help solve my community's problems & 5.88 & 1.196 \\
\hline 7.f. Keeping the business alive & 6.15 & 1.108 \\
\hline 7.g. Maintain a positive growth path & 6.24 & 1.012 \\
\hline \multicolumn{3}{|l|}{ Business Growth } \\
\hline 8. How important would it be for you to continually develop and grow your business? & 6.09 & 1.211 \\
\hline \multicolumn{3}{|l|}{ Being an Entrepreneur } \\
\hline B2.-Entrepreneur & 5.33 & 1.531 \\
\hline \multicolumn{3}{|l|}{ Business Strategy } \\
\hline 9.a. Export a significant part of production & 5.08 & 1.436 \\
\hline 9.b. Regularly introduce new products/services for my customers & 5.48 & 1.247 \\
\hline 9.c. Regularly introduce new production processes or systems & 5.24 & 1.286 \\
\hline 9.d. Develop research and development projects & 5.65 & 1.242 \\
\hline 9.e. Detailed planning of the different areas of the company & 5.79 & 1.189 \\
\hline 9.f. Reach cooperation agreements or partnerships with other companies & 5.75 & 1.184 \\
\hline 9.g. Provide specialized training for employees & 6.07 & 1.145 \\
\hline 9.h. Grow your business (staff, facilities, etc.) & 5.98 & 1.115 \\
\hline
\end{tabular}

In the Entrepreneurial Intention group, in average terms, the issues of greatest agreement amongst the respondents were the ones related to the commitment of all efforts to start and manage a new business (A06-4.89) and the determination to create an enterprise in the future (A13-4.47); in the questions of Perceived Behavior, the questions related to the perception of success (A14-4.64) and the perception of the ability to control the process of creating a new business (A07-4.6) were the ones that generated the greatest agreement, being that respondents demonstrated, on average, to have little knowledge of all the practical details needed to start a new business (A20-2.93). 
At Entrepreneurial Attitude, most respondents agree that they would love to open a new business (A10 - 5.74) and that being an entrepreneur would give them great satisfaction (A15-5.07). In terms of Business Skills, respondents showed more aptitude in terms of problem-solving skills (D3-5.39), leadership and communication skills (D4-5.28), as well as creativity (D2-5.02). As for Business Success, respondents consider it, on average, more important to maintain a positive growth path (7.g.-6.24), to do a type of work that they really appreciate (7.c.-6.16), and keep the business alive (7.f.-6.24).

Continuous development and business growth (Business Growth) is, on average, very important for respondents (8.-6.09) and they consider it, on average, to be an entrepreneur-Being an Entrepreneur (B2-5.33). Finally, in terms of Business Strategy, it is very likely, on average, that respondents will offer specialized training to their employees (9.g.-6.07), grow their business (9.h.-5.98), plan in detail the different areas of the company (9.e.-5.79), and establish cooperation agreements or partnerships with other companies (9.f.-5.75).

\section{Results Discussion}

The structural model shown in Figure 1 was estimated using the Partial Least Squares (PLS) method in the Smart PLS 3.0 software [93]. PLS is one of the approaches of Structural Equation Models (SEM), which allows estimating the causal relationships between variables, defined by a theoretical model. The nature of these relationships is not directly observable, so one or more indicators are used to measure them. The main focus of this technique is on the ability to be able to analyze the complexity of a system, based on a set of latent concepts and indicators, given by the Latent Variables and Manifest Variables, respectively [94]. In this manner, PLS is a structural variance-based model, used to develop theories in the context of exploratory research. Its objective is to maximize the explained variance between the dependent variables of the model, that is, the R Square value. Thus, it allows for the testing of complex theoretical relationships defined by the supporting literature and enhances the probability of identifying significant relationships between variables when in fact these relationships exist in the sample [95,96].

In the estimated model, eight latent variables were created: three endogenous latent variables (Entrepreneurial attitude, Entrepreneurial Intention, and Being an Entrepreneur) and five exogenous latent variables (Business Strategy, Business Growth, Business Success, Business Skills, and Perceived Behavior), as previously mentioned, and a total of 34 indicators were used. The use of the PLS model requires the validation of the sample size which, according to Hair, et al. [97], must be at least equal to one of the following conditions: (1) ten times the number of indicators, or (2) ten times the number of structural paths directed to a latent variable in the structural model. The sample has 1114 observations and, thus, is ten times greater than the number of indicators, fulfilling the first condition. On the other hand, there are seven structural paths between the latent variables, also fulfilling the second condition. We conclude that the sample used is suitable for the application of the PLS method. On the other hand, the application of this method does not require normal data, the measurement scale used is generally metric, and the ordinal scale is also accepted $[97,98]$.

To measure the quality of the model obtained by the PLS method, it is necessary to analyze the discrepancy between the values of the dependent variables, whether they are observed (in the case of manifest variables) or approximate (in the case of latent variables), and the value predicted by the model. Consequently, the overall quality of the model is given by its predictive capacity, and the measurement and structural models that compose it must be validated. One of the measures used is reliability and validity, that is, instruments for mediating the relationship between the latent and observed variables of the model, which implies an analysis of the reliability of each latent variable at the indicator level and the convergent and discriminant validity. For this, the indicator factor loadings, the reliability, and average variance extracted (AVE) of each indicator used should be analyzed, as shown in Table 3. 
Table 3. Results of the model's reliability and validity measures.

\begin{tabular}{|c|c|c|c|c|c|c|c|c|}
\hline & $\begin{array}{c}\text { Being an } \\
\text { Entrepreneur }\end{array}$ & $\begin{array}{l}\text { Business } \\
\text { Growth }\end{array}$ & $\begin{array}{l}\text { Business } \\
\text { Skills }\end{array}$ & $\begin{array}{l}\text { Business } \\
\text { Strategy }\end{array}$ & $\begin{array}{l}\text { Business } \\
\text { Success }\end{array}$ & $\begin{array}{c}\text { Entrep. } \\
\text { Attitude }\end{array}$ & $\begin{array}{c}\text { Entrep. } \\
\text { Intention }\end{array}$ & $\begin{array}{r}\text { Perceived } \\
\text { Behavior }\end{array}$ \\
\hline $7 \mathrm{~A}$ & & & & & 0.603 & & & \\
\hline $7 \mathrm{~B}$ & & & & & 0.717 & & & \\
\hline $7 \mathrm{C}$ & & & & & 0.656 & & & \\
\hline 7D & & & & & 0.610 & & & \\
\hline $7 \mathrm{E}$ & & & & & 0.683 & & & \\
\hline $7 \mathrm{~F}$ & & & & & 0.822 & & & \\
\hline $7 \mathrm{G}$ & & & & & 0.837 & & & \\
\hline 8 & & 1 & & & & & & \\
\hline $9 \mathrm{~A}$ & & & & 0.555 & & & & \\
\hline $9 \mathrm{~B}$ & & & & 0.763 & & & & \\
\hline $9 \mathrm{C}$ & & & & 0.749 & & & & \\
\hline 9D & & & & 0.775 & & & & \\
\hline $9 \mathrm{E}$ & & & & 0.779 & & & & \\
\hline $9 \mathrm{~F}$ & & & & 0.715 & & & & \\
\hline $9 \mathrm{G}$ & & & & 0.740 & & & & \\
\hline $9 \mathrm{H}$ & & & & 0.756 & & & & \\
\hline A04 & & & & & & & 0.824 & \\
\hline A06 & & & & & & & 0.799 & \\
\hline A13 & & & & & & & 0.880 & \\
\hline A17 & & & & & & & 0.871 & \\
\hline A01 & & & & & & & & 0.746 \\
\hline $\mathrm{A} 07$ & & & & & & & & 0.830 \\
\hline A14 & & & & & & & & 0.829 \\
\hline A20 & & & & & & & & 0.708 \\
\hline A10 & & & & & & 0.846 & & \\
\hline A15 & & & & & & 0.900 & & \\
\hline A18 & & & & & & 0.776 & & \\
\hline B2 & 1 & & & & & & & \\
\hline D1 & & & 0.766 & & & & & \\
\hline D2 & & & 0.715 & & & & & \\
\hline D3 & & & 0.729 & & & & & \\
\hline D4 & & & 0.757 & & & & & \\
\hline D5 & & & 0.812 & & & & & \\
\hline D6 & & & 0.711 & & & & & \\
\hline $\begin{array}{l}\text { Cronbach's } \\
\text { Alpha }\end{array}$ & 1 & 1 & 0.844 & 0.876 & 0.832 & 0.794 & 0.873 & 0.785 \\
\hline $\begin{array}{l}\text { Composite } \\
\text { Reliability }\end{array}$ & 1 & 1 & 0.885 & 0.902 & 0.875 & 0.880 & 0.913 & 0.861 \\
\hline $\begin{array}{l}\text { Average Variance } \\
\text { Extracted (AVE) }\end{array}$ & 1 & 1 & 0.561 & 0.536 & 0.503 & 0.710 & 0.725 & 0.608 \\
\hline
\end{tabular}

The reference value for reliability coefficients of latent variables is 0.70 (Hair et al., 2019). All the estimated reliability coefficients of the model are higher than the reference value as shown in Table 3 and as such, they are "satisfactory to good", meaning that all latent variables are above the acceptable values for the outer loadings, reliability, and validity of the model estimated.

Latent variables have high indicator loads (greater than 0.555 ) and acceptable validity and convergence measured by Cronbach's Alpha (all results of this indicator are greater than 0.700 -reference value). Cronbach's Alpha gives us an estimate of the reliability between the observed indicators and the corresponding latent variable. The Average Variance Extracted (AVE) of the latent variables indicates the estimate of how much the variation of the indicators is due to the inherent latent variable, having a reference value of 0.50 . In the estimated model, for all latent variables, a stroke greater than 0.50 was obtained.

Finally, the Fornell-Larcker criterion was used as a measure of Discriminant Validity since this criterion allows the analysis of cross-loadings that are indicators of the discriminant validity of latent variables. Table 4 shows the results of applying the FornellLarcker criterion. 
Table 4. Results of applying the Fornell-Larcker criterion.

\begin{tabular}{|c|c|c|c|c|c|c|c|c|}
\hline & $\begin{array}{c}\text { Being an } \\
\text { Entrepreneur }\end{array}$ & $\begin{array}{l}\text { Business } \\
\text { Growth }\end{array}$ & $\begin{array}{l}\text { Business } \\
\text { Skills }\end{array}$ & $\begin{array}{l}\text { Business } \\
\text { Strategy }\end{array}$ & $\begin{array}{l}\text { Business } \\
\text { Success }\end{array}$ & $\begin{array}{c}\text { Entrepreneurial } \\
\text { Attitude }\end{array}$ & $\begin{array}{l}\text { Entrepreneurial } \\
\text { Intention }\end{array}$ & $\begin{array}{l}\text { Perceived } \\
\text { Behavior }\end{array}$ \\
\hline Being an Entrepreneur & 1.0000 & & & & & & & \\
\hline Business Growth & 0.3982 & 1.0000 & & & & & & \\
\hline Business Skills & 0.4459 & 0.2936 & 0.7492 & & & & & \\
\hline Business Strategy & 0.3334 & 0.4980 & 0.3128 & 0.7320 & & & & \\
\hline Business Success & 0.3510 & 0.6182 & 0.2826 & 0.6482 & 0.7094 & & & \\
\hline Entrepreneurial Attitude & 0.7295 & 0.4452 & 0.4728 & 0.3188 & 0.3450 & 0.8424 & & \\
\hline Entrepreneurial Intention & 0.6920 & 0.3950 & 0.5335 & 0.3178 & 0.2948 & 0.6248 & 0.8517 & \\
\hline Perceived Behavior & 0.4895 & 0.2904 & 0.6378 & 0.2233 & 0.1988 & 0.5858 & 0.6855 & 0.7799 \\
\hline
\end{tabular}

Each AVE of the latent variables (elements in the main diagonal that are in bold) is superior to all the square correlations of the latent variables (elements outside the diagonal), thus establishing the discriminant validity of each of the eight latent variables.

The model has been validated by the measures of reliability and validity and discriminant validity, and the PLS algorithm in Smart PLS 3.0 was applied to this model, resulting in the PLS Path Model shown in Figure 2. In this model, the algorithm converged the parameter of the PLS-SEM algorithm (out of 300 iterations) after the 7 th iteration.

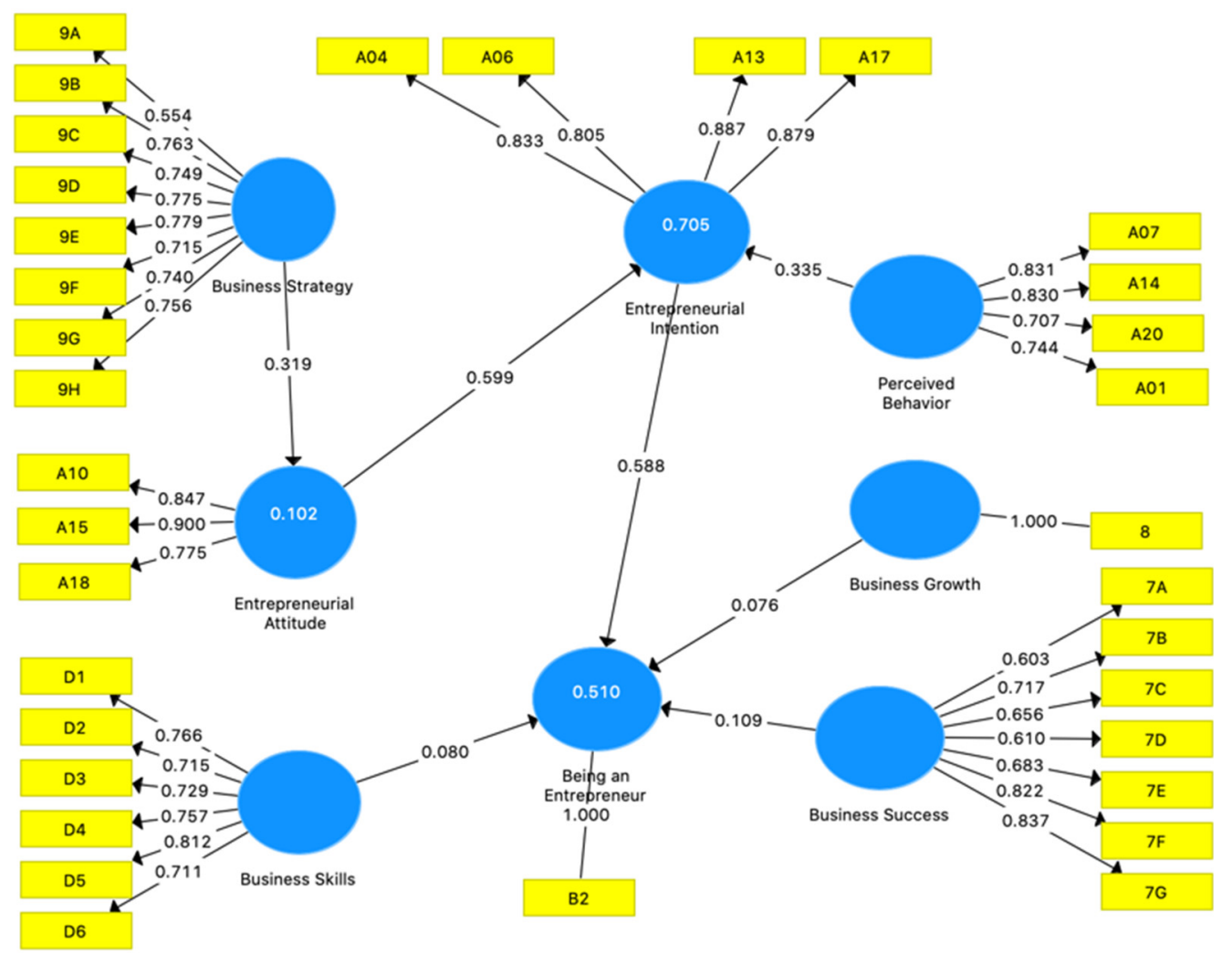

Figure 2. PLS Path Model.

The PLS Path Model contains the 34 collected indicators (represented in the rectangles) and the eight latent variables created-Entrepreneurial Intention, Perceived Behavior, Entrepreneurial Attitude, Business Strategy, Business Skills, Business Success, Business Growth, and Being an Entrepreneur. The structural relationships established between the latent variables are in accordance with the structural model shown in Figure 1.

The predictive precision of the PLS Path Model is assessed by analyzing the R Square $\left(\mathrm{R}^{2}\right)$ values of the endogenous (dependent) latent variables, that is, Being an Entrepreneur, Entrepreneurial Intention, and Entrepreneurial Attitude. Several authors report reference values for $\mathrm{R}^{2}$ to be different according to the areas of study. Ritchey [99], states that 0.02 represents a "small" effect, 0.15 represents a "medium" effect, and 0.35 represents a "high" effect. Hair, Sarstedt, Matthews and Ringle [97] considered that, in general, the reference 
$R^{2}$ values are $0.75,0.50$, and 0.25 and, consequently, the endogenous latent variables are, respectively, described as substantial, moderate, and weak. Höck and Ringle [100] state that $\mathrm{R}^{2}$ of $0.67,0.33$, and 0.19 are "substantial", "moderate", and "weak", respectively.

In this model, the $\mathrm{R}^{2}$ values of the endogenous latent variables are: Being an Entrepreneur $>0.510$, Entrepreneurial Intention $>0.705$ and Entrepreneurial Attitude $>0.102$. Following the most current criteria by Hair, Sarstedt, Matthews and Ringle [97], we can refer that the $R^{2}$ of the latent variables Being an Entrepreneur and Entrepreneurial Intention is "moderate" and the latent variable Entrepreneurial Attitude is "weak".

The significant relationships between the latent variables are measured by their path coefficients. As shown in Figure 2, there are significant relationships between the latent variables, the most significant being between Entrepreneurial Attitude > Entrepreneurial Intention $(0.599$, that is, a variation of $1 \%$ in the variable Entrepreneurial Attitude has a positive impact of $59.9 \%$ on the Entrepreneurial Intention variable) and between Entrepreneurial Intention > Being an Entrepreneur (0.588, that is, a $1 \%$ variation on the Entrepreneurial Intention variable has a positive impact of $58.8 \%$ in the Being an Entrepreneur variable).

Once the path coefficients were calculated, the bootstrap method was applied, with a significance level of $95 \%$, to test the hypotheses formulated in this study. This nonparametric technique allows analyzing the accuracy of the estimates of the PLS parameters. Its procedure is to obtain a specific number of sub-samples of the same size as the original sample. The selection of observations is made through sampling with replacement; to obtain more reasonable estimates, a high number of sub-samples is advised (in this study, in Smart PLS, 500 sub-samples were used).

Table 5 shows the results of applying the bootstrap method. We conclude that all latent variables are very significant at $p<0.05$, with $95 \%$ confidence.

Table 5. Significance Testing Results of the Structural Model Path Coefficients.

\begin{tabular}{|c|c|c|c|c|c|}
\hline & $\begin{array}{c}\text { Original Sample } \\
(\beta)\end{array}$ & $\begin{array}{l}\text { Sample Mean } \\
\text { (M) }\end{array}$ & $\begin{array}{c}\text { Standard Deviation } \\
\text { (STDEV) }\end{array}$ & $\begin{array}{l}\text { T Statistics } \\
\text { (|O/STDEV|) }\end{array}$ & $p$ Values \\
\hline H1: Business Growth -> Being an Entrepreneur & 0.0756 & 0.0721 & 0.0319 & 2.3700 & $0.0182 *$ \\
\hline H2: Business Skills -> Being an Entrepreneur & 0.0796 & 0.0812 & 0.0301 & 2.6418 & $0.0085 *$ \\
\hline H3: Business Strategy -> Entrepreneurial Attitude & 0.3188 & 0.3223 & 0.0271 & 11.7525 & $0.0000 *$ \\
\hline H4: Business Success -> Being an Entrepreneur & 0.1086 & 0.1115 & 0.0276 & 3.9307 & $0.0001 *$ \\
\hline H5: Entrepreneurial Attitude -> Entrepreneurial Intention & 0.5986 & 0.5987 & 0.0216 & 27.7516 & $0.0000 *$ \\
\hline H6: Entrepreneurial Intention -> Being an Entrepreneur & 0.5877 & 0.5869 & 0.0240 & 24.5309 & $0.0000 *$ \\
\hline H7: Perceived Behavior $->$ Entrepreneurial Intention & 0.3348 & 0.3353 & 0.0232 & 14.4061 & $0.0000 *$ \\
\hline
\end{tabular}

Note: ${ }^{*} p<0.05$. Source: authors' calculations.

In such a way, and following the conclusions by Birley, Cromie and Myers [79] and Donckels and Lambrecht [80], the results obtained reinforce the importance attributed by the undertaking of continuous development and business growth (Business Growth) has a positive impact $(\beta=0.0756)$ on the desire to be an entrepreneur, confirming Hypothesis 1 .

Greater Business Skills such as the recognition of opportunities, creativity, problemsolving skills, leadership and communication skills, ability to develop new products or services, and to form networks and professional contacts have a positive impact ( $\beta=0.0796)$ relationship previously mentioned by $[83,84]$.

As defended by Pobee and Mphela [75], Damke, Gimenez and Damke [81] and Hashimoto and Nassif [82], the results attained reveal that the use of business strategies to expand a business (Business Strategy) such as the export of a significant part of the production, the regular introduction of new products/services and production processes, the development of research projects and development, detailed planning of the different areas of the company, the establishment of agreements or partnerships with other companies, the provision of specialized training for employees, and the willingness to grow the business (in personnel and facilities) has a positive impact $(\beta=0.3188)$ on Entrepreneurial Attitude, thus confirming Hypotheses 3.

The valuation of Business Success factors such as effective competition in world markets, achieving a high level of income, doing work that is appreciated, being socially recognized, helping to solve the surrounding problems, keeping the business alive, and 
maintaining a path of positive growth has a positive impact $(\beta=0.1086)$ on the desire to be an entrepreneur, confirming Hypothesis 4. This significance confirms the studies developed by Mitchelmore and Rowley [85], Rasul, Bekun and Akadiri [86], Kummerow, Wilson, Ramayah and Hazlina Ahmad [87], Boyd and Vozikis [34], Anastasia [77], and Fillis and Rentschler [78].

The results also demonstrate that Entrepreneurial Attitude is measured by will, if there was an opportunity to start a new business, by the satisfaction of being an entrepreneur, and by the recognized advantages of being an entrepreneur has a positive impact $(\beta=0.5986)$ in Entrepreneurial Intention, confirming Hypothesis 5. This relationship has already been evidenced by several authors, including [38,42,72].

In turn, Entrepreneurial Intention, measured by the desire to be an entrepreneur at any cost, by the efforts committed to start or manage a business of its own, by the determination to create a business in the future, and by the professional objective of being an entrepreneur has a positive impact $(\beta=0.5877)$ on the desire to be an entrepreneur, confirming Hypothesis 6, according to what was advocated by Kristiansen and Indarti [76]. Finally, Perceived Behavior, measured by the ease of starting a company and keeping it viable, the ability to control the process of creating a new business, the likelihood of being successful in creating a business, and the knowledge of all the practical details needed to start a new business have a positive impact $(\beta=0.3348)$ on Entrepreneurial Intention, confirming Hypothesis 7. These results are in line with what has been reported in several studies, such as Linan, Urbano and Guerrero [37], Kolvereid [43], Krueger, Reilly and Carsrud [45], Fayolle and Gailly [47], and Vamvaka, Stoforos, Palaskas and Botsaris [72].

In addition to the direct path coefficients, the model also allows estimating four path coefficients of indirect effects (Table 6). Values are obtained, for example, for Entrepreneurial Attitude > Entrepreneurial Intention > Being an Entrepreneur (0.3518), making the product between the Entrepreneurial Attitude > Entrepreneurial Intention (0.5986) influence, and the Entrepreneurial Intention > Being an Entrepreneur (0.5877). It means that a 1\% variation in Entrepreneurial Attitude has an indirect impact of $35.18 \%$ on the Being an Entrepreneur latent variable. As we can see in Table 6, all indirect effects are statistically significant with $p=0.000$, for $95 \%$ bootstrap.

Table 6. Indirect and total effects estimation results.

\begin{tabular}{|c|c|c|c|c|c|}
\hline & $\begin{array}{l}\text { Original Sample } \\
\text { (O) }\end{array}$ & $\begin{array}{l}\text { Sample Mean } \\
\text { (M) }\end{array}$ & $\begin{array}{l}\text { Standard Deviation } \\
\text { (STDEV) }\end{array}$ & $\begin{array}{l}\text { T Statistics } \\
\text { (|O/STDEVI) }\end{array}$ & $p$ Values \\
\hline \multicolumn{6}{|l|}{ Indirect Effects } \\
\hline $\begin{array}{c}\text { Entrepreneurial Attitude -> Entrepreneurial Intention -> } \\
\text { Being an Entrepreneur }\end{array}$ & 0.3518 & 0.3515 & 0.0211 & 16.6401 & 0.0000 * \\
\hline $\begin{array}{c}\text { Business Strategy }->\text { Entrepreneurial Attitude -> } \\
\text { Entrepreneurial Intention }\end{array}$ & 0.1908 & 0.1930 & 0.0181 & 10.5362 & 0.0000 * \\
\hline $\begin{array}{l}\text { Business Strategy }->\text { Entrepreneurial Attitude }-> \\
\text { Entrepreneurial Intention }->\text { Being an Entrepreneur }\end{array}$ & 0.1121 & 0.1133 & 0.0114 & 9.8406 & $0.0000 *$ \\
\hline $\begin{array}{c}\text { Perceived Behavior }->\text { Entrepreneurial Intention }->\text { Being an } \\
\text { Entrepreneur }\end{array}$ & 0.1968 & 0.1967 & 0.0146 & 13.4463 & 0.0000 * \\
\hline \multicolumn{6}{|l|}{ Total Effects } \\
\hline Business Growth $->$ Being an Entrepreneur & 0.0756 & 0.0721 & 0.0319 & 2.3700 & $0.0182 *$ \\
\hline Business Skills -> Being an Entrepreneur & 0.0796 & 0.0812 & 0.0301 & 2.6418 & $0.0085^{*}$ \\
\hline Business Strategy $->$ Being an Entrepreneur & 0.1121 & 0.1133 & 0.0114 & 9.8406 & $0.0000 *$ \\
\hline Business Strategy $->$ Entrepreneurial Attitude & 0.3188 & 0.3223 & 0.0271 & 11.7525 & 0.0000 * \\
\hline Business Strategy $->$ Entrepreneurial Intention & 0.1908 & 0.1930 & 0.0181 & 10.5362 & 0.0000 * \\
\hline Business Success -> Being an Entrepreneur & 0.1086 & 0.1115 & 0.0276 & 3.9307 & $0.0001 *$ \\
\hline Entrepreneurial Attitude $->$ Being an Entrepreneur & 0.3518 & 0.3515 & 0.0211 & 16.6401 & $0.0000 *$ \\
\hline Entrepreneurial Attitude -> Entrepreneurial Intention & 0.5986 & 0.5987 & 0.0216 & 27.7516 & $0.0000 *$ \\
\hline Entrepreneurial Intention -> Being an Entrepreneur & 0.5877 & 0.5869 & 0.0240 & 24.5309 & 0.0000 * \\
\hline Perceived Behavior $->$ Being an Entrepreneur & 0.1968 & 0.1967 & 0.0146 & 13.4463 & $0.0000 *$ \\
\hline Perceived Behavior -> Entrepreneurial Intention & 0.3348 & 0.3353 & 0.0232 & 14.4061 & 0.0000 * \\
\hline
\end{tabular}

Note: ${ }^{*} p<0.05$ and the $95 \%$ bootstrap. Source: authors' calculations.

Also in Table 6, the total effects of exogenous latent variables on endogenous latent variables are represented, with the most expressive total effects being verified in the influence of Entrepreneurial Attitude $>$ Entrepreneurial Intention (0.5986) and Entrepreneurial 
Intention $>$ Being an Entrepreneur (0.5877). All total effects are statistically significant at $p<0.05$ to $95 \%$ bootstrap.

We can also conclude that the indirect effects and the total effects confirm the results obtained in the significance test (Table 5), that is, there is a direct, indirect, and total positive influence of Business Growth, Business Skills, Business Success, and Entrepreneurial Intention in the will to be an entrepreneur (Being an Entrepreneur) and there is also a positive influence of Business Strategy in Entrepreneurial Attitude and Perceived Behavior in Entrepreneurial Intention, confirming again all the hypotheses formulated in this study (Table 7).

Table 7. Hypothesis formulation summary.

\begin{tabular}{cc}
\hline Hypothesis & Supported/Not Supported \\
\hline H1: The importance attached to Business Growth has a positive impact on the will to be an entrepreneur. & Supported \\
\hline H2: Greater Business Skills have a positive impact on the will to be an entrepreneur. & Supported \\
\hline H3: The use of Business Strategy for business expansion has a positive impact on Entrepreneurial Attitude. & Supported \\
\hline H4: The appreciation of Business Success factors has a positive impact on the will to be an entrepreneur. & Supported \\
\hline H5: Entrepreneurial Attitude has a positive impact on Entrepreneurial Intention. & Supported \\
\hline H6: Entrepreneurial Intention has a positive impact on the will to be an entrepreneur. & Supported \\
\hline H7: Perceived Behavior has a positive impact on Entrepreneurial Intention. & Supported \\
\hline
\end{tabular}

\section{Conclusions}

In the context of cooperation with and for the community, through the integration of business groups and social partners, universities develop activities that go beyond training by transferring knowledge, which has a fundamental importance in the development of the region and country where they operate. Inside the university boundaries, academic training may potentiate a wish within the students to follow entrepreneurial activities.

Within this framework emerges the main objective of this research, which aims to evaluate the determinants that influence the interest of Portuguese higher education students to become entrepreneurs. Based on the development of a structural model, and grounded by the relevant literature, which studies the direct and indirect relationships between the variables Entrepreneurial Attitude, Entrepreneurial Intention, Being an Entrepreneur, Business Strategy, Business Growth, Business Success, Business Skills, and Perceived behavior, a total of 34 indicators were accounted.

The results allowed us to conclude that several factors influence the entrepreneurial intentions of higher education students. Specifically, in line with the relevant literature, we found that the will to be an entrepreneur, and therefore the entrepreneurial intention, is directly affected by behavioral variables (such as entrepreneurial attitude and perceived behavior), as well as by the perception of young people in the workplace, which refers to aspects related to the business (including business growth, business strategy, business success) and business skills.

Being so, we confirm the vital role of universities in the training of future entrepreneurs, not only by providing the development of behavioral, social, and technical skills for students to develop their business in the future but also by allowing them to integrate a set of networks and projects, which allow them to identify/perceive the value of projects in terms of their business growth, business strategy, and business success.

This research contributed to the theory by adding new knowledge to the literature on the perception of the HEI's students to become entrepreneurs, specifically the students of Portuguese universities. In practical terms, the contributions offered within this research are based on suggestions on the third mission of universities and knowledge transfer to the community, business groups, and policy makers, as well as the creation of the essentials within university limits to promote entrepreneurship amongst its students. 
Attracting more students for entrepreneurship, innovation, and knowledge transfer to companies and communities will be increased, thus allowing economic growth and development and job creation.

This research is original and innovative, as no research on this field and with all the aggregated elements under study was performed in Portugal. Moreover, this research provides universities and other local entities with the knowledge of drivers that capture the interest of students, and thus creates projects and training that go according to their motivations.

As for clues for future investigations, it would be significant to integrate into this study other variables, which according to the relevant literature, may influence the entrepreneurial intention of higher education students in Portugal, namely, the students' perception of the norms and institutions in which they are inserted, for example, regulations, financing, advice, and instruments to support entrepreneurship. It is also important to compare the results obtained in Portugal with results from other countries in which entrepreneurship is more interesting and captivating, and where the rates of creation of companies by recent graduates are higher. In order to assess the more active role of universities as drivers of entrepreneurial activity, we must also assess the existence of entrepreneurship promotion centers provided by universities, the existence of incumbents of new companies and the contents of the entrepreneurship subjects that make up the plans evaluated of higher education students. From this analysis, lessons can be learned about the policies and strategies to be adopted in promoting entrepreneurship in Portugal and in creating jobs through nascent entrepreneurship.

Another possibility for future research could be the production of a longitudinal study, which has the advantage of showing the evolution of the indicators over time and making temporal comparisons. Thus, it would be pertinent, for example, to compare student behavior in an environment of economic growth and recession.

Author Contributions: Conceptualization, J.M.L.; Data curation, J.O. and S.G.; Formal analysis, J.O.; Investigation, J.M.L., M.O., M.S. and T.S.; Methodology, S.G.; Project administration, J.M.L.; Resources, M.O.; Software, J.O. and S.G.; Supervision, J.M.L.; Validation, S.G.; Visualization, S.G.; Writing—original draft, M.O., M.S., T.S. and S.G.; Writing—review and editing, M.O., J.O., M.S. and T.S. All authors have read and agreed to the published version of the manuscript.

Funding: NECE-UBI, Research Centre for Business Sciences, Research Centre and this work are funded by FCT—Fundação para a Ciência e a Tecnologia, IP, project UIDB/04630/2020.

Institutional Review Board Statement: The study was conducted according to the guidelines of the Declaration of Helsinki and approved by the Institutional Review Board.

Informed Consent Statement: Informed consent was obtained from all subjects involved in the study.

Data Availability Statement: Not applicable.

Acknowledgments: The authors would like to thank the ISPGAYA, ISLA Santarem, Polytechnic Institute of Leiria, CICS.NOVA-Interdisciplinary Center for Social Sciences, Faculty of Social and Human Sciences (FCSH/NOVA), Miguel Torga Institute of Higher Education, University of Beira Interior, NECE-Research Unit in Business Sciences, University Portucalense, and REMIT-Research on Economics, Management and Information Technologies for their support.

Conflicts of Interest: The authors declare no conflict of interest.

\section{References}

1. Mei, H.; Lee, C.-H.; Xiang, Y. Entrepreneurship Education and Students' Entrepreneurial Intention in Higher Education. Educ. Sci. 2020, 10, 257. [CrossRef]

2. Lopes, J.; Antunes, H.; Rodrigues, R. Comparative Entrepreneurship between Western Europe and Latin America. Entrep. Res. J. 2018, 8. [CrossRef]

3. Dentoni, D.; Pinkse, J.; Lubberink, R. Linking Sustainable Business Models to Socio-Ecological Resilience Through Cross-Sector Partnerships: A Complex Adaptive Systems View. Bus. Soc. 2021, 60, 1216-1252. [CrossRef] 
4. Belz, F.M.; Binder, J.K. Sustainable Entrepreneurship: A Convergent Process Model. Bus. Strategy Environ. $2017,26,1-17$. [CrossRef]

5. Benneworth, P.; Charles, D. University spin-off policies and economic development in Less successful regions: Learning from two decades of policy practice. Eur. Plan. Stud. 2005, 13, 537-557. [CrossRef]

6. Lamine, W.; Fayolle, A.; Mian, S. How do social skills enable nascent entrepreneurs to enact perseverance strategies in the face of challenges? A comparative case study of success and failure. Int. J. Entrep. Behav. Res. 2014, 20, 517-541. [CrossRef]

7. Miller, K.; McAdam, R.; Moffett, S.; Alexander, A.; Puthusserry, P. Knowledge transfer in university quadruple helix ecosystems: An absorptive capacity perspective. RD Manag. 2016, 46, 383-399. [CrossRef]

8. Lopes, J.; Franco, M. Review About Regional Development Networks: An Ecosystem Model Proposal. J. Knowl. Econ. 2019, 10, 275-297. [CrossRef]

9. Brown, W.; Galloway, L. Entrepreneurship education at university: A driver in the creation of high growth firms? Educ. + Train. 2002, 44, 398-405. [CrossRef]

10. Bezerra, É.D.; Borges, C.; Andreassi, T. Universities, local partnerships and the promotion of youth entrepreneurship. Int. Rev. Educ. 2017, 63, 703-724. [CrossRef]

11. Etzkowitz, H.; Webster, A.; Gebhardt, C.; Terra, B.R.C. The future of the university and the university of the future: Evolution of ivory tower to entrepreneurial paradigm. Res. Policy 2000, 29, 313-330. [CrossRef]

12. Lopes, J.; Lussuamo, J. Barriers to University-Industry Cooperation in a Developing Region. J. Knowl. Econ. 2020, 12, 1019-1035. [CrossRef]

13. Rothaermel, F.T.; Agung, S.D.; Jiang, L. University entrepreneurship: A taxonomy of the literature. Ind. Corp. Chang. 2007, 16, 691-791. [CrossRef]

14. Davey, T. Converting university knowledge into value: How conceptual frameworks contribute to the understanding of the third mission role of European universities. Int. J. Technol. Transf. Commer. 2017, 15, 65-96. [CrossRef]

15. Lopes, J.; Ferreira, J.J.; Farinha, L. Innovation strategies for smart specialisation (RIS3): Past, present and future research. Growth Chang. 2019, 50, 38-68. [CrossRef]

16. Markuerkiaga, L.; Errasti, N.; Igartua, J.I. Success Factors for Managing an Entrepreneurial University: Developing an Integrative Framework. Ind. High. Educ. 2014, 28, 233-244. [CrossRef]

17. Neves, S.; Brito, C. Academic entrepreneurship intentions: A systematic literature review. J. Manag. Dev. 2020, 39, 645-704. [CrossRef]

18. Tlaiss, H.A. Entrepreneurial motivations of women: Evidence from the United Arab Emirates. Int. Small Bus. J. 2015, 33, 562-581. [CrossRef]

19. Farrukh, M.; Khan, A.A.; Shahid Khan, M.; Soladoye, B.S.A.; Ravan Ramzani, S. Entrepreneurial intentions: The role of family factors, personality traits and self-efficacy. World J. Entrep. Manag. Sustain. Dev. 2017, 13, 303-317. [CrossRef]

20. Antoncic, B.; Bratkovic kregar, T.; Singh, G.; Denoble, A.F. The Big Five Personality-Entrepreneurship Relationship: Evidence from Slovenia. J. Small Bus. Manag. 2015, 53, 819-841. [CrossRef]

21. Karimi, S.; Biemans, H.J.A.; Naderi Mahdei, K.; Lans, T.; Chizari, M.; Mulder, M. Testing the relationship between personality characteristics, contextual factors and entrepreneurial intentions in a developing country. Int J. Psychol. 2017, 52, 227-240. [CrossRef] [PubMed]

22. Hossain, M.D.; Al Asheq, A.; Arifuzzaman, S.M. Entrepreneurial intention of Bangladeshi students: Impact of individual and contextual factors. Probl. Perspect. Manag. 2019, 17, 493-503. [CrossRef]

23. Zhao, H.; Seibert, S.E.; Lumpkin, G.T. The relationship of personality to entrepreneurial intentions and performance: A metaanalytic review. J. Manag. 2010, 36, 381-404. [CrossRef]

24. Reissová, A.; Šimsová, J.; Sonntag, R.; Kučerová, K. The influence of personal characteristics on entrepreneurial intentions: International comparison. Entrep. Bus. Econ. Rev. 2020, 8, 29-46. [CrossRef]

25. Taylor, M.P. Earnings, independence or unemployment: Why become self-employed? Oxf. Bull. Econ. Stat. 1996, 58, 253-266. [CrossRef]

26. Carr, J.C.; Sequeira, J.M. Prior family business exposure as intergenerational influence and entrepreneurial intent: A Theory of Planned Behavior approach. J. Bus. Res. 2007, 60, 1090-1098. [CrossRef]

27. Wagner, J.; Sternberg, R. Start-up activities, individual characteristics, and the regional milieu: Lessons for entrepreneurship support policies from German micro data. Ann. Reg. Sci. 2004, 38, 219-240. [CrossRef]

28. Wang, Y.H.; Lee, C.H.; Trappey, A.J.C. Modularized design-oriented systematic inventive thinking approach supporting collaborative service innovations. Adv. Eng. Inform. 2017, 33, 300-313. [CrossRef]

29. Lee, C.-H.; Chen, C.-H.; Trappey, A.J.C. A structural service innovation approach for designing smart product service systems: Case study of smart beauty service. Adv. Eng. Inform. 2019, 40, 154-167. [CrossRef]

30. Lopes, J.; Teixeira, S.J.; Ferreira, J.J.M.; Silveira, P.; Farinha, L.; Lussuamo, J. University entrepreneurial intentions: Mainland and insular regions-Are they different? Educ. + Train. 2020, 62, 81-99. [CrossRef]

31. Anjum, T.; Farrukh, M.; Heidler, P.; Díaz Tautiva, J.A. Entrepreneurial Intention: Creativity, Entrepreneurship, and University Support. J. Open Innov. Technol. Mark. Complex. 2021, 7, 11. [CrossRef]

32. Ajzen, I. Nature and Operation of Attitudes. Annu. Rev. Psychol. 2001, 52, 27-58. [CrossRef] [PubMed]

33. Bird, B. Implementing Entrepreneurial Ideas: The Case for Intention. Acad. Manag. Rev. 1988, 13, 442-453. [CrossRef] 
34. Boyd, N.G.; Vozikis, G.S. The Influence of Self-Efficacy on the Development of Entrepreneurial Intentions and Actions. Entrep. Theory Pract. 1994, 18, 63-77. [CrossRef]

35. Fini, R.; Grimaldi, R.; Marzocchi, G.L.; Sobrero, M. The Determinants of Corporate Entrepreneurial Intention within Small and Newly Established Firms. Entrep. Theory Pract. 2012, 36, 387-414. [CrossRef]

36. Thompson, E.R. Individual Entrepreneurial Intent: Construct Clarification and Development of an Internationally Reliable Metric. Entrep. Theory Pract. 2009, 33, 669-694. [CrossRef]

37. Linan, F.; Urbano, D.; Guerrero, M. Regional variations in entrepreneurial cognitions: Start-up intentions of university students in Spain. Entrep. Reg. Dev. 2011, 23, 187-215. [CrossRef]

38. Ajzen, I. The theory of planned behavior. Organ. Behav. Hum. Decis. Process. 1991, 50, 179-211. [CrossRef]

39. North, D.C. Institutions, Institutional Change and Economic Performance; Cambridge University Press: Cambridge, UK, 1990.

40. Anderson, A.R.; Jack, S.L. The articulation of social capital in entrepreneurial networks: A glue or a lubricant? Entrep. Reg. Dev. 2002, 14, 193-210. [CrossRef]

41. Liñán, F.; Santos, F.J. Does social capital affect entrepreneurial intentions? Int. Adv. Econ. Res. 2007, 13, 443-453. [CrossRef]

42. Ajzen, I. Perceived Behavioral Control, Self-Efficacy, Locus of Control, and the Theory of Planned Behavior. J. Appl. Soc. Psychol. 2002, 32, 665-683. [CrossRef]

43. Kolvereid, L. Prediction of Employment Status Choice Intentions. Entrep. Theory Pract. 1996, 21, 47-58. [CrossRef]

44. Kolvereid, L.; Isaksen, E. New business start-up and subsequent entry into self-employment. J. Bus. Ventur. 2006, 21, 866-885. [CrossRef]

45. Krueger, N.F.; Reilly, M.D.; Carsrud, A.L. Competing models of entrepreneurial intentions. J. Bus. Ventur. 2000, 15, 411-432. [CrossRef]

46. Krueger, N.F. What Lies Beneath? The Experiential Essence of Entrepreneurial Thinking. Entrep. Theory Pract. 2007, 31, 123-138. [CrossRef]

47. Fayolle, A.; Gailly, B. The Impact of Entrepreneurship Education on Entrepreneurial Attitudes and Intention: Hysteresis and Persistence. J. Small Bus. Manag. 2015, 53, 75-93. [CrossRef]

48. Davidsson, P.; Henrekson, M. Determinants of the Prevalance of Start-ups and High-Growth Firms. Small Bus. Econ. 2002, 19, 81-104. [CrossRef]

49. Mueller, S.L.; Thomas, A.S. Culture and entrepreneurial potential: A nine country study of locus of control and innovativeness. J. Bus. Ventur. 2001, 16, 51-75. [CrossRef]

50. Hayton, J.C.; George, G.; Zahra, S.A. National Culture and Entrepreneurship: A Review of Behavioral Research. Entrep. Theory Pract. 2002, 26, 33-52. [CrossRef]

51. Spilling, O.R. Entrepreneurship in a cultural perspective. Entrep. Reg. Dev. 1991, 3, 33-48. [CrossRef]

52. Hoang, H.; Antoncic, B. Network-based research in entrepreneurship: A critical review. J. Bus. Ventur. 2003, 18, 165-187. [CrossRef]

53. Greve, A.; Salaff, J.W. Social Networks and Entrepreneurship. Entrep. Theory Pract. 2003, 28, 1-22. [CrossRef]

54. Iakovleva, T.; Kolvereid, L.; Stephan, U. Entrepreneurial intentions in developing and developed countries. Educ. + Train. 2011, 53, 353-370. [CrossRef]

55. Armitage, C.J.; Conner, M. Efficacy of the Theory of Planned Behaviour: A meta-analytic review. Br. J. Soc. Psychol. 2001, 40, 471-499. [CrossRef]

56. Huang, S.; Ding, D.; Chen, Z. Entrepreneurial Leadership and Performance in Chinese New Ventures: A Moderated Mediation Model of Exploratory Innovation, Exploitative Innovation and Environmental Dynamism. Creat. Innov. Manag. 2014, $23,453-471$. [CrossRef]

57. Kraft, P.; Bausch, A. How Do Transformational Leaders Promote Exploratory and Exploitative Innovation? Examining the Black Box through MASEM. J. Prod. Innov. Manag. 2016, 33, 687-707. [CrossRef]

58. Covin, J.G.; Lumpkin, G.T. Entrepreneurial Orientation Theory and Research: Reflections on a Needed Construct. Entrep. Theory Pract. 2011, 35, 855-872. [CrossRef]

59. Welter, F.; Smallbone, D. Institutional Perspectives on Entrepreneurial Behavior in Challenging Environments. J. Small Bus. Manag. 2011, 49, 107-125. [CrossRef]

60. Musteen, M.; Curran, R.; Arroteia, N.; Ripollés, M.; Blesa, A. A Community of Practice Approach to Teaching International Entrepreneurship. Adm. Sci. 2018, 8, 56. [CrossRef]

61. Rotefoss, B.; Kolvereid, L. Aspiring, nascent and fledgling entrepreneurs: An investigation of the business start-up process. Entrep. Reg. Dev. 2005, 17, 109-127. [CrossRef]

62. Tkachev, A.; Kolvereid, L. Self-employment intentions among Russian students. Entrep. Reg. Dev. 1999, 11, 269-280. [CrossRef]

63. Lüthje, C.; Franke, N. The 'making' of an entrepreneur: Testing a model of entrepreneurial intent among engineering students at MIT. RD Manag. 2003, 33, 135-147. [CrossRef]

64. Ajzen, I. The theory of planned behaviour: Reactions and reflections. Psychol. Health 2011, 26, 1113-1127. [CrossRef]

65. Miranda, F.J.; Chamorro-Mera, A.; Rubio, S. Academic entrepreneurship in Spanish universities: An analysis of the determinants of entrepreneurial intention. Eur. Res. Manag. Bus. Econ. 2017, 23, 113-122. [CrossRef]

66. Compagnucci, L.; Spigarelli, F. The Third Mission of the university: A systematic literature review on potentials and constraints. Technol. Forecast. Soc. Chang. 2020, 161, 120284. [CrossRef] 
67. Jong, S.; Barker, K.; Cox, D.; Sveinsdottir, T.; Van den Besselaar, P. Understanding societal impact through productive interactions: ICT research as a case. Res. Eval. 2014, 23, 89-102. [CrossRef]

68. Miller, K.; McAdam, R.; McAdam, M. A systematic literature review of university technology transfer from a quadruple helix perspective: Toward a research agenda. RD Manag. 2018, 48, 7-24. [CrossRef]

69. Leydesdorff, L. The Triple Helix, Quadruple Helix, ... , and an N-Tuple of Helices: Explanatory Models for Analyzing the Knowledge-Based Economy? J. Knowl. Econ. 2012, 3, 25-35. [CrossRef]

70. Carayannis, E.G.; Barth, T.D.; Campbell, D.F.J. The Quintuple Helix innovation model: Global warming as a challenge and driver for innovation. J. Innov. Entrep. 2012, 1, 2. [CrossRef]

71. Bozeman, B.; Rimes, H.; Youtie, J. The evolving state-of-the-art in technology transfer research: Revisiting the contingent effectiveness model. Res. Policy 2015, 44, 34-49. [CrossRef]

72. Vamvaka, V.; Stoforos, C.; Palaskas, T.; Botsaris, C. Attitude toward entrepreneurship, perceived behavioral control, and entrepreneurial intention: Dimensionality, structural relationships, and gender differences. J. Innov. Entrep. 2020, 9, 5. [CrossRef]

73. Forliano, C.; De Bernardi, P.; Yahiaoui, D. Entrepreneurial universities: A bibliometric analysis within the business and management domains. Technol. Forecast. Soc. Chang. 2021, 165, 120522. [CrossRef]

74. Nabi, G.; Liñán, F.; Fayolle, A.; Krueger, N.; Walmsley, A. The Impact of Entrepreneurship Education in Higher Education: A Systematic Review and Research Agenda. Acad. Manag. Learn. Educ. 2017, 16, 277-299. [CrossRef]

75. Pobee, F.; Mphela, T. An Analysis of the Entrepreneurial Ecosystem of Malawi: The Global Entrepreneurship Index (GEI) Approach. J. Dev. Commun. Stud. 2021, 8, 224-238. [CrossRef]

76. Kristiansen, S.; Indarti, N. Entrepreneurial Intention among Indonesian and Norwegian Students. J. Enterprising Cult. 2004, 12, 55-78. [CrossRef]

77. Anastasia, C. Exploring definitions of small business and why it is so difficult. J. Manag. Policy Pract. 2015, 16, 88.

78. Fillis, I.A.N.; Rentschler, R. The Role of Creativity in Entrepreneurship. J. Enterprising Cult. 2011, 18, 49-81. [CrossRef]

79. Birley, S.; Cromie, S.; Myers, A. Entrepreneurial Networks: Their Emergence in Ireland and Overseas. Int. Small Bus. J. 1991, 9 , 56-74. [CrossRef]

80. Donckels, R.; Lambrecht, J. Networks and small business growth: An explanatory model. Small Bus. Econ. 1995, 7, 273-289. [CrossRef]

81. Damke, E.; Gimenez, F.A.P.; Damke, J.F.W. Strategic configurations and performance: A study in micro and small business retailers. Rausp Manag. J. 2018, 53, 11-22. [CrossRef]

82. Hashimoto, M.; Nassif, V.M.J. Inhibition and Encouragement of Entrepreneurial Behavior: Antecedents Analysis from Managers' Perspectives. Braz. Adm. Rev. 2014, 11, 385-I. [CrossRef]

83. Velasco, R.M. The making of an entrepreneur: Aligning institutional paradigm to the industry needs. J. Bus. Retail. Manag. Res. 2016, 10, 81-92.

84. Ozaralli, N.; Rivenburgh, N.K. Entrepreneurial intention: Antecedents to entrepreneurial behavior in the U.S.A. and Turkey. J. Glob. Entrep. Res. 2016, 6, 1-32. [CrossRef]

85. Mitchelmore, S.; Rowley, J. Entrepreneurial competencies of women entrepreneurs pursuing business growth. J. Small Bus. Enterp. Dev. 2013, 20, 125-142. [CrossRef]

86. Rasul, O.; Bekun, F.V.; Akadiri, S.S. The Impact of Self-efficacy on International Student Entrepreneur Intention. Int. Rev. Manag. Mark. 2017, 7, 169-174.

87. Kummerow, L.; Wilson, C.; Ramayah, T.; Hazlina Ahmad, N. Is entrepreneurial competency and business success relationship contingent upon business environment? Int. J. Entrep. Behav. Res. 2010, 16, 182-203. [CrossRef]

88. Ferreira, J.; Paco, A.; Raposo, M.; Hadjichristodoulou, C.; Marouchou, D. International entrepreneurship education: Barriers versus support mechanisms to STEM students. J. Int. Entrep. 2020, 19, 130-147. [CrossRef]

89. Hlady-rispal, M.; Jouison-laffitte, E. Qualitative Research Methods and Epistemological Frameworks: A Review of Publication Trends in Entrepreneurship. J. Small Bus. Manag. 2014, 52, 594-614. [CrossRef]

90. Queirós, A.; Faria, D.; Almeida, F. Strengths and limitations of qualitative and quantitative research methods. Eur. J. Educ. Stud. 2017, 3, 369-387. [CrossRef]

91. Choy, L.T. The strengths and weaknesses of research methodology: Comparison and complimentary between qualitative and quantitative approaches. IOSR J. Humanit. Soc. Sci. 2014, 19, 99-104. [CrossRef]

92. Bryman, A. The Debate About Quantitative and Qualitative Research-A Question of Method or Epistemology. Br. J. Sociol. 1984, 35, 75-92. [CrossRef]

93. Ringle, C.M.; Sarstedt, M. Gain more insight from your PLS-SEM results The importance-performance map analysis. Ind. Manag. Data Syst. 2016, 116, 1865-1886. [CrossRef]

94. Henseler, J.; Hubona, G.; Ray, P.A. Using PLS path modeling in new technology research: Updated guidelines. Ind. Manag. Data Syst. 2016, 116, 2-20. [CrossRef]

95. Ringle, C.M.; Sarstedt, M.; Mitchell, R.; Gudergan, S.P. Partial least squares structural equation modeling in HRM research. Int. J. Hum. Resour. Manag. 2020, 31, 1617-1643. [CrossRef]

96. Hair, J.F.; Risher, J.J.; Sarstedt, M.; Ringle, C.M. When to use and how to report the results of PLS-SEM. Eur. Bus. Rev. 2019, 31, 2-24. [CrossRef] 
97. Hair, J.J.F.; Sarstedt, M.; Matthews, L.M.; Ringle, C.M. Identifying and treating unobserved heterogeneity with FIMIX-PLS: Part I-Method. Eur. Bus. Rev. 2016, 28, 63-76. [CrossRef]

98. Matthews, L.M.; Sarstedt, M.; Hair, J.F.; Ringle, C.M. Identifying and treating unobserved heterogeneity with FIMIX-PLS: Part II-A case study. Eur. Bus. Rev. 2016, 28, 208-224. [CrossRef]

99. Ritchey, F.J. The Statistical Imagination: Elementary Statistics for the Social Sciences, 2nd ed.; McGraw-Hill: New York, NY, USA, 2008.

100. Höck, M.; Ringle, C.M. Strategic networks in the software industry: An empirical analysis of the value continuum. In Proceedings of the IFSAM VIIIth World Congress, Berlin, Germany, 28-30 September 2006; p. 2010. 